\title{
Genetic population structure of Anopheles gambiae in Equatorial
} Guinea

\author{
Marta Moreno*1, Patricia Salgueiro ${ }^{2}$, José Luis Vicente ${ }^{2}$, Jorge Cano ${ }^{1,3}$, \\ Pedro J Berzosa ${ }^{1}$, Aida de Lucio ${ }^{1}$, Frederic Simard ${ }^{4} 5$, Adalgisa Caccone ${ }^{6}$, \\ Virgilio E Do Rosario², João Pinto ${ }^{2}$ and Agustín Benito ${ }^{1}$
}

\begin{abstract}
Address: ${ }^{1}$ Centro Nacional de Medicina Tropical. Instituto de Salud Carlos III. C/Sinesio Delgado 4, 28029 Madrid, Spain, ${ }^{2}$ Centro de Malária e outras Doenças Tropicais, Instituto de Higiene e Medicina Tropical, Universidade Nova de Lisboa, Lisbon, Portugal, ${ }^{3}$ Centro de Referencia para el Control de Endemias. Centro Nacional de Medicina Tropical, Instituto de Salud Carlos III, Bata, Equatorial Guinea, ${ }^{4}$ Institut de Recherche pour le Développement, Unité 016, Montpellier, France, ${ }^{5}$ Organisation de Coordination pour la Lutte contre les Endémies en Afrique Centrale, Yaoundé, Cameroun and ' $Y$ Yale Institute for Biospheric Studies and Department of Ecology and Evolutionary Biology, Yale University, New Haven, USA
\end{abstract}

Email: Marta Moreno* - martamor@isciii.es; Patricia Salgueiro - Psalgueiro@ihmt.unl.pt; José Luis Vicente - JoseLuis@ihmt.unl.pt; Jorge Cano - jcano@isciii.es; Pedro J Berzosa - pberzosa@isciii.es; Aida de Lucio - aida@isciii.es; Frederic Simard - Frederic.Simard@ird.fr; Adalgisa Caccone - adalgisa.caccone@yale.edu; Virgilio E Do Rosario - CMDT@ihmt.unl.pt; João Pinto - JPinto@ihmt.unl.pt; Agustín Benito - abenito@isciii.es

* Corresponding author

Published: 15 October 2007

Malaria Journal 2007, 6:137 doi:10.1186/1475-2875-6-137
Received: 18 June 2007

Accepted: 15 October 2007

This article is available from: http://www.malariajournal.com/content/6/I/137

(c) 2007 Moreno et al; licensee BioMed Central Ltd.

This is an Open Access article distributed under the terms of the Creative Commons Attribution License (http://creativecommons.org/licenses/by/2.0), which permits unrestricted use, distribution, and reproduction in any medium, provided the original work is properly cited.

\begin{abstract}
Background: Patterns of genetic structure among mosquito vector populations in islands have received particular attention as these are considered potentially suitable sites for experimental trials on transgenic-based malaria control strategies. In this study, levels of genetic differentiation have been estimated between populations of Anopheles gambiae s.s. from the islands of Bioko and Annobón, and from continental Equatorial Guinea (EG) and Gabon.

Methods: Genotyping of II microsatellite loci located in chromosome 3 was performed in three island samples (two in Bioko and one in Annobón) and three mainland samples (two in EG and one in Gabon). Four samples belonged to the M molecular form and two to the S-form. Microsatellite data was used to estimate genetic diversity parameters, perform demographic equilibrium tests and analyse population differentiation.

Results: High levels of genetic differentiation were found between the more geographically remote island of Annobón and the continent, contrasting with the shallow differentiation between Bioko island, closest to mainland, and continental localities. In Bioko, differentiation between $M$ and $S$ forms was higher than that observed between island and mainland samples of the same molecular form.

Conclusion: The observed patterns of population structure seem to be governed by the presence of both physical (the ocean) and biological (the M-S form discontinuity) barriers to gene flow. The significant degree of genetic isolation between $M$ and $S$ forms detected by microsatellite loci located outside the "genomic islands" of speciation identified in A. gambiae s.s. further supports the hypothesis of on-going incipient speciation within this species. The implications of these findings regarding vector control strategies are discussed.
\end{abstract}




\section{Background}

Malaria is an infectious disease that causes between 300500 million annual clinical cases and 1.5-3 million deaths per year, mainly in children under five years old in sub-Saharan Africa [1]. Classical strategies of vector control developed in endemic areas of Africa, such as impregnated bed nets or indoor residual spraying, have not been as effective as expected, and malaria incidence is increasing. Among the factors involved in this failure are the lack of sustainability of vector control programmes and the emergence of insecticide resistance in mosquitoes [2].

Genetically based methods have been proposed for malaria vector control. These methods focus mainly in altering vectorial capacity through the genetic transformation of natural vector populations by means of introducing refractoriness genes or by sterile insect technologies [3]. Knowledge of the genetic structure of vector species is, therefore, an essential requirement as it should contribute not only to predict the spread of genes of interest, such as insecticide resistance or refractory genes, but also to identify heterogeneities in disease transmission due to distinct vector populations [4]. The most effective Afrotropical malaria vectors belong to the Anopheles gambiae complex, that comprises seven sibling species. Within the complex, A. gambiae sensu stricto (s.s.) is the most synanthropic species and shows remarkable genetic heterogeneity $[5,6]$. Cytogenetic analysis has revealed different chromosomal arrangements associated with paracentric inversions [5]. This has lead to the description of five chromosomal forms based in differences in the frequencies of polymorphic arrangements, geographical distribution and ecological data [5,7]. Furthermore, analysis of the X-linked ribosomal DNA cluster suggested further genetic subdivision within A. gambiae s.s. and led to the description of two molecular forms, provisionally named $M$ and $S$, defined based on sequence differences in transcribed and non-transcribed rDNA spacers (IGS and ITS) [8,9]. Although the offspring between $\mathrm{M}$ and $\mathrm{S}$ forms are viable and fertile [10], M-S hybrids or cross-mating between the two forms are rarely observed in nature [6,11]. Genetic differentiation between molecular forms in this primary vector is of paramount relevance for the implementation and monitoring of its control, as illustrated by the extreme differences found in the distribution of knockdown resistance mutations among sympatric $\mathrm{M}$ and $\mathrm{S}$ form populations $[12,13]$.

Previous population genetic studies pointed to a shallow population structure within major malaria vectors throughout the African continent, possibly as a result of recent population expansion leading to substantial retention of ancestral polymorphism $[14,15]$. The few cases of significant population differentiation have been attributed to barriers to gene flow, either physical or biological in the case of the M-S form partitioning in A. gambiae s.s. [16-19] However, recent studies suggest further subdivision within each of the molecular forms, as evidenced by significant levels of genetic differentiation among populations of different chromosomal forms, revealed by microsatellites and AFLP markers [20,21].

In Equatorial Guinea, malaria is one of the main causes of morbidity and mortality, being transmitted mainly by vectors of the A. gambiae complex [22]. In the island of Bioko, as well as in mainland Equatorial Guinea, both $M$ and $\mathrm{S}$ forms are known to occur in sympatry. Different vector control measures are being implemented, including insecticide treated bed nets and indoors residual spraying [23]. However, studies regarding the genetic structure of A. gambiae s.s. remain scarce for Equatorial Guinea. The geography of the country, formed by both insular and continental regions, is likely to promote a greater biological heterogeneity among its vector populations. This may have important implications for the design and implementation of nationwide malaria vector control programmes. In addition, islands are regarded as potential sites for experimental releases of transgenic mosquitoes for malaria control, increasing the need for further genetic studies of its populations $[18,24]$.

In this study, microsatellite markers have been used to estimate levels of genetic differentiation between populations of A. gambiae s.s. from the islands of Bioko and Annobón and from continental localities of Equatorial Guinea and Gabon, in order to determine the extent of population substructuring and its association with barriers to gene flow.

\section{Methods \\ Mosquito collections and species identification}

Entomological surveys took place in five localities of Equatorial Guinea, situated in the Gulf of Guinea, West Africa (Figure 1). In the island of Bioko, situated ca. 200 $\mathrm{km}$ from mainland Equatorial Guinea, landing and indoors resting collections were conducted in 2003 in Malabo $\left(3^{\circ} 45^{\prime} \mathrm{N} / 8^{\circ} 46^{\prime} \mathrm{E}\right)$, capital of the country, and in the village of Sácriba $\left(3^{\circ} 42^{\prime} \mathrm{N} / 8^{\circ} 43^{\prime} \mathrm{E}\right) 9 \mathrm{~km}$ away. On the island of Annobón, located in the South hemisphere 670 $\mathrm{km}$ away from Bioko and $585 \mathrm{~km}$ off mainland Equatorial Guinea, samples were collected by CDC light traps and landing catches in 2004. In the mainland, collections were carried out in 2004 in Bata $\left(1^{\circ} 52^{\prime} \mathrm{N} / 9^{\circ} 46^{\prime} \mathrm{E}\right)$ and Ngonamanga $\left(2^{\circ} 08^{\prime} \mathrm{N} / 9^{\circ} 46^{\prime} \mathrm{E}\right) 30 \mathrm{~km}$ apart, by the same sampling methods. Climatic and ecological data from these sites have been described elsewhere [22].

Mosquitoes were morphologically identified using the identification keys of Gillies \& Coetzee [25]. Specimens were kept individually in silica gel filled tubes at $4^{\circ} \mathrm{C}$, 


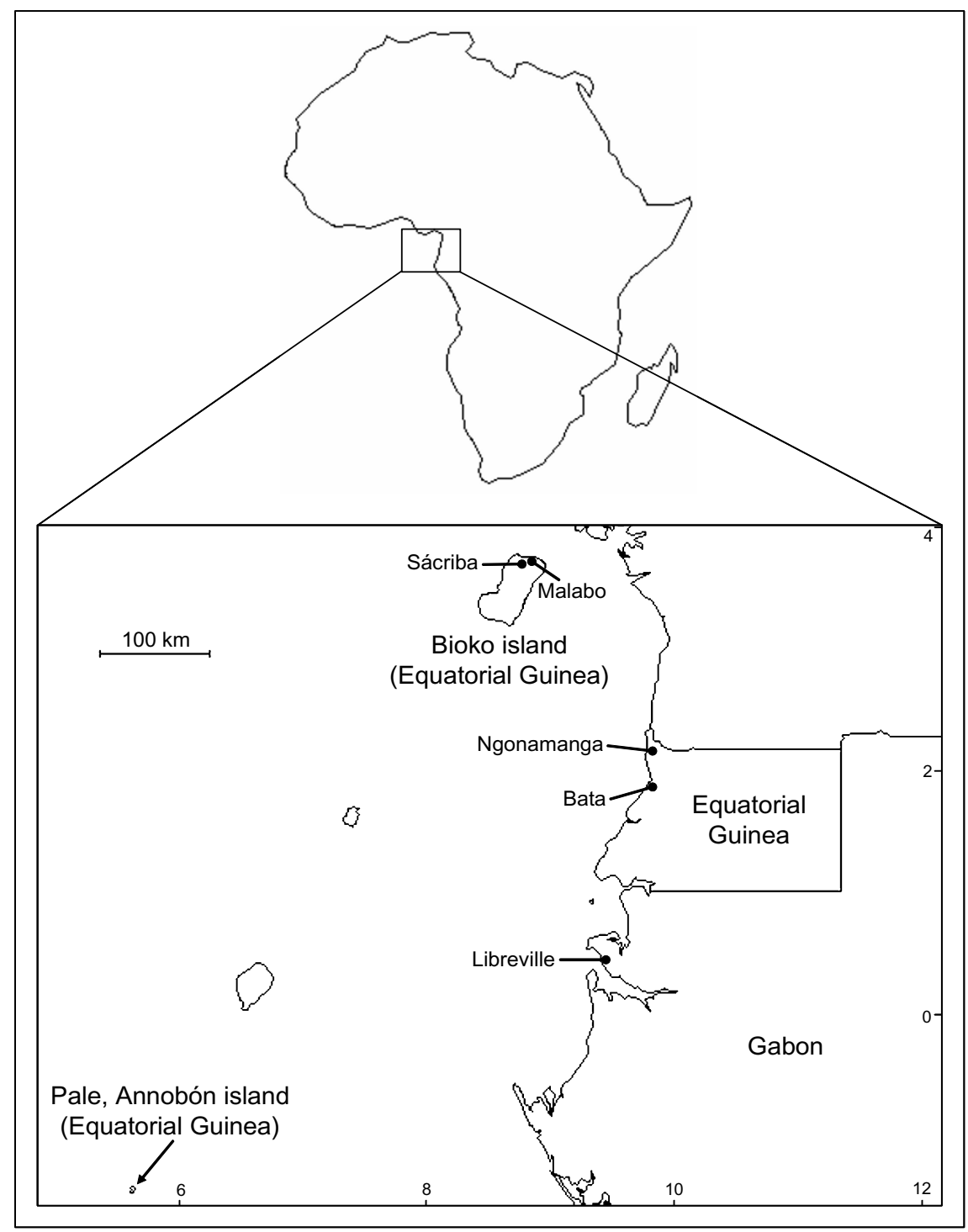

Figure I

Collection sites in Equatorial Guinea and Gabon.

until DNA extraction was performed according to Collins et al [26]. Species identification within the A. gambiae complex was done by PCR according to Scott et al [27]. Anopheles gambiae s.s. molecular forms were determined as described in Favia et al [28]. Although cytological analysis was not performed, the Forest cytoform of A. gambiae s.s. is likely to be the only one present in these localities $[5,22]$.

An additional sample from Libreville $\left(0^{\circ} 23^{\prime} \mathrm{N} / 9^{\circ} 27^{\prime} \mathrm{E}\right)$, Gabon, was also included in the analysis. This sample was collected in 2000 and it is composed by S-form A. gambiae s.s. [29].

\section{Microsatellite analysis}

Eleven microsatellite loci $[17,30]$ were genotyped: Ag3H128, Ag3H249, Ag3H119, Ag3H242, Ag3H577, Ag3H555, Ag3H59, Ag3H758, Ag3H88, Ag3H93 and $45 \mathrm{C} 1$. Only loci of chromosome 3 were used to avoid possible bias due to selective effects associated with paracentric inversions or reproductive isolation putative regions that are known to occur in chromosomes 2 and X [31,32]. Each locus was amplified by PCR using fluorescently labelled (FAM, NED, or HEX) forward primers [33]. Amplified fragments were separated by capillary electrophoresis in an automatic sequencer (ABI 3730, Applied Biosystems) and sizes scored using the software GeneMarker (SoftGenetics, USA). 


\section{Data analysis}

Genetic diversity by locus and sample was characterized by estimates of unbiased expected heterozygosity $\left(H_{e^{\prime}}\right.$ [34]), and allele richness [35], available in FSTAT v 2.9.3.2 [36]. The latter estimate was used instead of the number of alleles per locus to account for differences in sample sizes. To account for differences in sample size, these estimates were re-calculated using randomly selected subsamples of each locality of size equal to the smallest sample size. Genotypic frequencies were tested against HardyWeinberg Equilibrium (HWE) proportions by exact probability tests performed in GENEPOP v.3.4 [37]. Linkage disequilibrium to confirm independence between loci was tested by exact tests on contingency tables, also available in GENEPOP.

Heterozygosity tests [38] were used to detect deviations from mutation-drift equilibrium (MDE). These tests compare two estimates of expected heterozygosity, one based on allele frequencies $\left(H_{e}\right)$, assuming Hardy-Weinberg proportions, and another based on the number of alleles and sample size $\left(H_{e q}\right)$, assuming MDE. At MDE, both estimates should be similar in the majority of loci analysed (i.e. $H_{e}=H_{e q}$ ). If a population experiences a bottleneck, rare alleles will be rapidly lost and therefore $H_{e q}$ will decrease faster than $H_{e}$ (i.e. $H_{e}>H_{e q}$ ). This apparent excess of heterozygosity in a significant number of loci is an indicator of a bottleneck, whereas the converse $\left(\right.$ i.e. $H_{e}<H_{e q}$ ) may indicate a population expansion. Estimates of expected heterozygosity under MDE were calculated under the Stepwise Mutation Model (SMM) and Two Phase Models (TPM) with $10-30 \%$ indels larger than the repeat unit. Calculations were done using the software BOTTLENECK 1.2.02. [38].

Differentiation among populations was measured by the fixation index $F_{\mathrm{ST}}$, calculated according to Weir and Cockerham [39] using ARLEQUIN v.3.01 [40]. Permutation tests $(10,100$ permutations) were performed in order to determine if estimates differed significantly from zero. The correlation between genetic and geographical distances, assuming isolation by distance, was assessed by the regression $F_{\mathrm{ST}} /\left(1-F_{\mathrm{ST}}\right)$ on the logarithm (ln) of pairwise geographical distances [41]. Significance of the correlation coefficient was tested using Mantel tests available in GENEPOP.

To compute the probability that an individual belonged to each reference population, assignment tests were performed on the basis of multilocus genotype data using GENECLASS 2.0 [42]. The Bayesian method of Rannala and Mountain [43] was used as the computation criterion and a re-sampling algorithm based on Paetkau et al [44] was employed. Data was run using 10,000 simulations and a threshold of significance $\alpha=0.01$.
Finally, a Bayesian approach was used to infer the number of clusters $(K)$ in the data set without prior information of the sampling locations, available in STRUCTURE 2 [45]. A model where the allele frequencies were correlated within populations was assumed ( $\lambda$ was set at 1 , the default value). The software was run with the option of admixture, allowing for some mixed ancestry within individuals, and $\alpha$ was allowed to vary. Twenty independent runs were done for each value of $K(\mathrm{~K}=1$ to 9$)$, with a burn-in period of 100,000 iterations and 100,000 replications. The method of Evanno et al [46] was used to determine the most likely number of clusters. This approach uses an ad hoc quantity, $\Delta K$, based on the second order rate of change of the likelihood function between successive values of $K$.

Whenever multiple tests were performed the nominal significance level ( $\alpha=0.05)$ was adjusted by the sequential Bonferroni procedure [47].

\section{Results}

\section{Species and molecular form identification}

A total of 213 female A. gambiae s.s. were analysed in this study. Of these, 133 individuals were of the M molecular form, corresponding to the samples of Ngonamanga (45) and Bata (28) on the continent, Malabo (36) in the island of Bioko and Annobón (24). The sample of Sácriba (35), in Bioko, and the sample of Gabon (45) were composed by $\mathrm{S}$-form individuals. Both molecular forms were found in sympatry in Ngonamanga and in both localities of Bioko island. However, the low numbers $(N<20)$ of $S-$ form individuals collected in these localities (or M-form in the case of Sácriba) precluded further analyses. The samples of Annobón and Bata had only M-form individuals and in Gabon only the S-form has been reported [29].

\section{Within population genetic variability}

Polymorphism at microsatellite loci varied, with allelic richness per locus ranging between four (Ag3H577 and 45C1) and 11 (Ag3H128). Two loci, Ag3H555 and 45C1, were monomorphic in Annobón. This island showed the lowest average allelic richness (3) compared to all other localities (7-8) and also had the lowest mean expected heterozygosity (0.436). The lowest genetic diversity cannot be explained by the low sample size for Annobón, as comparable differences were obtained when data was reanalysed using randomly selected sub-samples of $N=24$ for all sites other than Annobón (Table 1). The average expected heterozygosity across all samples ranged from 0.540 (Ag3H577) to 0.789 (AgH128), with significant heterozygote deficits detected in four loci. Within each sample, significant heterozygote deficits were detected only in four occasions, in locus Ag3H88 (Malabo and Libreville), Ag3H758 (Ngonamanga) and Ag3H93 (Sácriba) (Table 1). Linkage disequilibrium tests revealed 
Table I: Genetic variability at microsatellite loci in $A$. gambiae s.s. from the localities surveyed

\begin{tabular}{|c|c|c|c|c|c|c|c|c|}
\hline Locus & & $\begin{array}{l}\text { Annobón [M] } \\
\text { Far-island (24) }\end{array}$ & $\begin{array}{c}\text { Malabo [M] } \\
\text { Near-island (36) }\end{array}$ & $\begin{array}{l}\text { Sácriba [S] Near- } \\
\text { island (35) }\end{array}$ & $\begin{array}{c}\text { Bata [M] } \\
\text { Mainland (28) }\end{array}$ & $\begin{array}{l}\text { Ngonamanga [M] } \\
\text { Mainland (45) }\end{array}$ & $\begin{array}{l}\text { Libreville [S] } \\
\text { Mainland (45) }\end{array}$ & $\begin{array}{c}\text { All Samples } \\
(213)\end{array}$ \\
\hline \multirow[t]{2}{*}{$\mathrm{Ag} 3 \mathrm{H} 242$} & $R_{s}$ & 3 & 5 & 7 & 4 & 6 & 5 & 5 \\
\hline & $H_{\mathrm{e}}$ & 0.613 & 0.654 & 0.635 & 0.634 & 0.679 & 0.646 & 0.644 \\
\hline \multirow[t]{2}{*}{$\mathrm{Ag} 3 \mathrm{HI} 28$} & $R_{s}$ & 4 & 10 & 10 & 16 & 17 & 7 & II \\
\hline & $\mathrm{H}_{\mathrm{e}}^{\mathrm{s}}$ & 0.659 & 0.849 & 0.721 & 0.919 & 0.921 & 0.666 & 0.789 \\
\hline \multirow[t]{2}{*}{$\mathrm{Ag} 3 \mathrm{H} 249$} & $R_{s}$ & 5 & 6 & 8 & 8 & 7 & 7 & 7 \\
\hline & $H_{\mathrm{e}}$ & 0.702 & 0.811 & 0.789 & 0.835 & 0.795 & 0.792 & 0.787 \\
\hline \multirow[t]{2}{*}{$\mathrm{Ag} 3 \mathrm{HI} I 9$} & $R_{s}$ & 2 & 6 & 10 & 5 & 7 & 9 & 7 \\
\hline & $H_{\mathrm{e}}$ & 0.190 & 0.688 & 0.839 & 0.745 & 0.738 & 0.826 & 0.671 \\
\hline \multirow[t]{2}{*}{$\mathrm{Ag} 3 \mathrm{H} 555$} & $R_{s}$ & I & 6 & 7 & 7 & 5 & 6 & 5 \\
\hline & $\mathrm{H}_{\mathrm{e}}$ & - & 0.763 & 0.748 & 0.738 & 0.614 & 0.785 & 0.608 \\
\hline \multirow[t]{2}{*}{$\mathrm{Ag} 3 \mathrm{H} 577$} & $R_{s}^{e}$ & 2 & 5 & 5 & 4 & 5 & 5 & 4 \\
\hline & $H_{\mathrm{e}}^{\mathrm{s}}$ & 0.386 & 0.569 & 0.626 & 0.536 & 0.611 & 0.509 & 0.540 \\
\hline \multirow[t]{2}{*}{$\mathrm{Ag} 3 \mathrm{H} 59$} & $R_{s}$ & 4 & 7 & 10 & 7 & 7 & 7 & 7 \\
\hline & $H_{\mathrm{e}}^{3}$ & 0.727 & 0.652 & 0.873 & 0.705 & 0.763 & 0.746 & 0.744 \\
\hline \multirow[t]{2}{*}{$\mathrm{Ag} 3 \mathrm{H} 88$} & $R_{s}$ & 3 & 10 & 7 & 10 & 10 & 6 & 8 \\
\hline & $\mathrm{H}_{\mathrm{e}}^{\mathrm{s}}$ & 0.519 & 0.840 & 0.801 & 0.838 & 0.871 & 0.731 & 0.767 \\
\hline \multirow[t]{2}{*}{ Ag3H758 } & $R_{s}^{\mathrm{e}}$ & 2 & II & 9 & 12 & 13 & 7 & 9 \\
\hline & $\mathrm{H}_{\mathrm{e}}$ & 0.500 & 0.882 & 0.787 & 0.886 & 0.896 & 0.669 & 0.770 \\
\hline \multirow[t]{2}{*}{$\mathrm{Ag} 3 \mathrm{H} 93$} & $R_{s}$ & 2 & 5 & 7 & 7 & 7 & 12 & 7 \\
\hline & $H_{\mathrm{e}}$ & 0.504 & 0.757 & 0.675 & 0.731 & 0.718 & 0.862 & 0.708 \\
\hline \multirow[t]{2}{*}{$45 \mathrm{Cl}$} & $R_{s}$ & I & 5 & 5 & 5 & 4 & 5 & 4 \\
\hline & $H_{\mathrm{e}}^{3}$ & - & 0.701 & 0.651 & 0.722 & 0.694 & 0.593 & 0.560 \\
\hline \multirow[t]{2}{*}{ All loci } & $R_{s}$ & 3 & 7 & 8 & 8 & 8 & 7 & 7 \\
\hline & $H_{\mathrm{e}}$ & 0.436 & 0.742 & 0.740 & 0.754 & 0.755 & 0.711 & 0.690 \\
\hline \multirow[t]{2}{*}{$N=24$} & $R_{s}$ & 3 & 8 & 7 & 8 & 7 & 7 & 9 \\
\hline & $H_{\mathrm{e}}^{3}$ & 0.436 & 0.768 & 0.744 & 0.763 & 0.740 & 0.706 & 0.693 \\
\hline
\end{tabular}

First row indicates collection sites and location (island or mainland), molecular form in square brackets [M or S] and sample size in parenthesis; $R_{s}$ : Allele richness; $H_{e}$ : Nei's unbiased estimate of expected heterozygosity. All loci/samples: mean values over loci or populations; In bold: significant heterozygote deficits according to exact tests against Hardy-Weinberg proportions after corrections for multiple testing by the sequential Bonferroni procedure. $N=24$ : estimates made with a sample size of 24 individuals for all localities.

a single significant association, for the pair Ag3H128/ Ag3H758 in Libreville. Altogether these results indicate that each sample represents a single panmictic gene pool.

Cornuet and Luikart's [38] heterozygosity tests showed significant deviations from MDE in the Annobón sample under all mutational models, with an apparent heterozygote excess indicating a recent bottleneck (Table 2 ). In the Malabo sample, all tests were non-significant regardless of the mutation model. For the remaining samples, a significant number of loci showing an apparent heterozygote deficit were detected at least under the SMM, suggesting recent population expansion.

\section{Genetic differentiation and isolation by distance}

Pairwise estimates of $F_{\mathrm{ST}}$ over all loci between samples are presented in Table 3. The Annobón sample showed the highest degree of differentiation from all other samples $\left(F_{\mathrm{ST}}=0.196-0.269, P<0.001\right)$. Genetic differentiation was higher between $M$ and $S$ form samples within Bioko island $\left(F_{\mathrm{ST}}=0.089, P<0.001\right)$ than between the $\mathrm{M}$-form samples from Bioko and mainland Equatorial Guinea $\left(F_{\mathrm{ST}}\right.$
$=0.023-0.042, P<0.001)$ or between the S-form samples from Bioko and Gabon $\left(F_{\mathrm{ST}}=0.050, P<0.001\right)$. The only non-significant $F_{\mathrm{ST}}$ estimate was the one involving the two continental M-form samples, Bata and Ngonamanga. No statistically significant correlations were detected between genetic differentiation, measured by $F_{\mathrm{ST}}$, and geographic distances (Mantel tests: $r=0.62, P=0.051$ ), even when tests were carried out with $\mathrm{M}$-form samples only (Mantel tests: $\mathrm{r}=0.84, P=0.084$ ).

Results of the assignment tests [42] showed that on average $62.9 \%$ (134 out of 213 ) of the individuals were correctly assigned to their original sampling site (Table 4). The collections from Annobón and Sácriba presented the highest proportion of correctly assigned individuals $(0.88$ and 0.89 , respectively). Over $81 \%$ of the 79 mis-assignments occurred between samples of the same molecular form, independent of geographic origin (within $\mathrm{M}$-form: 0.62; within S-form: 0.19; between forms: 0.19). Within the M-form, nearly half of the individuals from Malabo, in Bioko island, were assigned to mainland Bata and nearly $60 \%$ of individuals from Ngonamanga were also mis- 
Table 2: Cornuet and Luikart's heterozygosity tests in A. gambiae s.s. from Equatorial Guinea and Gabon

\begin{tabular}{|c|c|c|c|c|c|}
\hline & & SMM & TPM (90\%) & TPM (80\%) & TPM (70\%) \\
\hline \multirow[t]{2}{*}{ Annobón [M] (far-island) } & $H_{\mathrm{e}}>H_{\mathrm{eq}}$ & 8 & 8 & 8 & 8 \\
\hline & $\left.P_{(\mathrm{He}}>\mathrm{Heq}\right)$ & 0.005 & 0.003 & 0.002 & 0.002 \\
\hline \multirow[t]{2}{*}{ Malabo [M] (near-island) } & $H_{\mathrm{e}}>\mathrm{H}_{\mathrm{eq}}$ & 3 & 6 & 7 & 8 \\
\hline & $\left.P_{(\mathrm{He}}>\mathrm{Heq}\right)$ & 0.913 & 0.517 & 0.289 & 0.160 \\
\hline \multirow[t]{2}{*}{ Sácriba [S] (near-island) } & $H_{\mathrm{e}}>H_{\mathrm{eq}}$ & $I^{*}$ & $2 *$ & 3 & 4 \\
\hline & $\left.P_{(\mathrm{He}}>\mathrm{Heq}\right)$ & 1.000 & 0.998 & 0.991 & 0.926 \\
\hline \multirow[t]{2}{*}{ Bata [M] (mainland) } & $H_{e}>H_{e q}$ & $4 *$ & 4 & 4 & 5 \\
\hline & $\left.P_{(\mathrm{He}}>\mathrm{Heq}\right)$ & 0.992 & 0.794 & 0.585 & 0.382 \\
\hline \multirow[t]{2}{*}{ Ngonamanga [M] (mainland) } & $H_{e}>H_{e q}$ & $2^{*}$ & 2 & 5 & 5 \\
\hline & $\left.P_{(\mathrm{He}}>\mathrm{Heq}\right)$ & 0.998 & 0.966 & 0.768 & 0.740 \\
\hline \multirow[t]{2}{*}{ Libreville [S] (mainland) } & $H_{\mathrm{e}}>H_{\mathrm{eq}}$ & $I^{*}$ & $2 *$ & 4 & 5 \\
\hline & $\left.P_{(\mathrm{He}}>\mathrm{Heq}\right)$ & 1.000 & 0.995 & 0.912 & 0.768 \\
\hline
\end{tabular}

First column indicates collection sites and location (island or mainland), and molecular form in square brackets [M or S]. SMM: stepwise mutation model; TPM: two-phase mutation model with indels larger than one repeat of $10 \%, 20 \%$ and $30 \%$, respectively; $H_{e}>H_{e q}$ : number of loci showing a heterozygote excess (II polymorphic loci in all localities except Annobón with 9); $\left.P_{(\mathrm{He}}>\mathrm{Heq}\right): P$-value of Wilcoxon tests to determine the significance of the number of loci in which $H_{\mathrm{e}}>H_{\mathrm{eq}}$. In bold are $P$-values that remained significant after adjustment by the sequential Bonferroni procedure. *: Significant number of loci in which $H_{\mathrm{e}}<H_{\mathrm{eq}}$ by Wilcoxon tests, also after adjustment of the nominal significance value.

assigned to Bata. Similarly, within the S-form over 30\% of the individuals from Libreville were mis-assigned to Sácriba, in Bioko.

Bayesian cluster analysis performed with STRUCTURE [45] showed that the most likely $K$ value identified was $K$ $=3$ (Figure 2a). This corresponds to three distinct genetic clusters (Figure 2b): (1) M-form A. gambiae s.s. from Annobón Island; (2) M-form samples from Bioko island (Malabo) and the mainland (Bata and Ngonamanga); (3) S-form samples from Bioko island (Sácriba) and the mainland (Libreville).

\section{Discussion}

Genetic diversity varied among island A. gambiae s.s.populations from Equatorial Guinea. In Bioko, levels of genetic variation in both $\mathrm{M}$ and S-forms were quite similar to those observed in the three continental samples. When compared with neighbouring mainland countries, mean expected heterozygosity values were similar to those reported for both molecular forms in Cameroon $\left(H_{e}\right.$ : $0.77-0.81 ;[16])$, Nigeria $\left(H_{e}: 0.76-0.79 ;[48]\right)$ and Ghana $\left(H_{e}: 0.71-0.82 ;[49]\right)$. In other islands in close proximity with mainland, genetic diversity was also similar to that of adjacent continental ones [24]. In contrast, the sample from the island of Annobón showed much lower levels of genetic diversity than Bioko samples. Bioko and Annobón lie at the opposite extremes of a volcanic chain in the Gulf of Guinea, which also includes the archipelago of São Tomé and Príncipe (STP). In these islands, estimates of genetic diversity were intermediate to those found in Bioko and Annobón $\left(H_{e}: 0.45-0.55 ;[18]\right)$. These findings overall agree with principles of island biogeography, in which biological (and genetic) diversity is positively correlated with the size of the island and negatively correlated with distance from mainland [50].

The heterozygosity tests suggested an expansion process in both $\mathrm{M}$ and S-form continental populations of A. gambiae s.s., in agreement with previous works based on mainland populations of this species [51]. Within the island of Bioko, the differences found between $\mathrm{M}$ and $\mathrm{S}$ samples may indicate different historical processes. While the $\mathrm{M}$ form was found at MDE, the S-form appears to be expanding. This pattern could be due to different timings of arrival of the two molecular forms on the island. The M-

Table 3: Estimates of pairwise $F_{S T}$ among populations of $A$. gambiae s.s. from Equatorial Guinea and Gabon.

\begin{tabular}{|c|c|c|c|c|c|}
\hline & Annobón & Malabo & Sácriba & Bata & Ngonamanga \\
\hline Annobón [M] (far-island) & - & & & & \\
\hline Malabo [M] (near-island) & 0.212 & - & & & \\
\hline Sácriba [S] (near-island) & 0.269 & 0.089 & - & & \\
\hline Bata [M] (mainland) & 0.196 & 0.023 & 0.080 & - & \\
\hline Ngonamanga [M] (mainland) & 0.187 & 0.042 & 0.079 & 0.003 & - \\
\hline Libreville [S] (mainland) & 0.267 & 0.109 & 0.050 & 0.100 & 0.099 \\
\hline
\end{tabular}

First column indicates collection sites and location (island or mainland), and molecular form in square brackets [M or S]. In Bold: significant estimate according to permutation tests ( 10,100 permutations) 
Table 4: Results of assignment tests based on microsatellite gene frequencies among samples of $A$. gambiae s.s. from Equatorial Guinea and Gabon.

\begin{tabular}{lcccccc}
\hline & Annobón [M] & Malabo [M] & Sácriba [S] & Bata [M] & Ngonamanga [M] & Libreville [S] \\
\hline Annobón [M] (far-island) & $\mathbf{0 . 8 8}$ & - & - & 0.12 & - & - \\
Malabo [M] (near-island) & - & $\mathbf{0 . 4 4}$ & 0.08 & 0.42 & 0.06 & - \\
Sácriba [S] (near-island) & - & - & $\mathbf{0 . 8 9}$ & 0.03 & 0.05 & 0.03 \\
Bata [M] (mainland) & - & - & 0.07 & $\mathbf{0 . 8 2}$ & - & $\mathbf{0 . 2 7}$ \\
Ngonamanga [M] (mainland) & - & - & 0.16 & 0.57 & - & $\mathbf{0 . 6 9}$ \\
Libreville [S] (mainland) & - & - & - & & -31 & \\
\hline
\end{tabular}

First column indicates collection sites and location (island or mainland), and molecular form in square brackets [M or S]. Values are proportions of individuals from the original sample (lines) assigned to each locality (columns). Proportions of individuals correctly assigned are shown in bold;

form A. gambiae s.s. individuals might have been the first to be introduced and thus have reached MDE, while the genetic signature of population expansion in the S-form sample could be due to its more recent establishment on the island.

The signature of population contraction detected in Annobón may be a consequence of several factors that need further examination. These may include a more

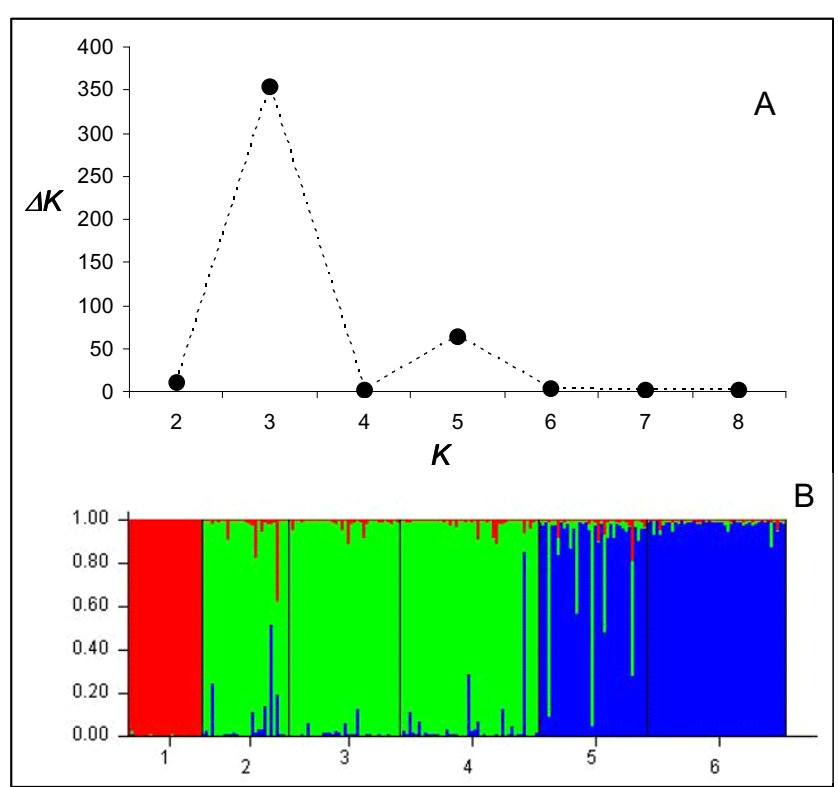

Figure 2

Bayesian cluster analysis using STRUCTURE. A: estimates of $\Delta K$, based on the second order rate of change of the likelihood function with respect to $K$, to determine the most likely number of clusters $(K)$ in the data set. In this case $K=$ 3. B: graphical representation of the data set for the most likely $K=3$, where each colour corresponds to a suggested cluster and each individual is represented by a vertical bar. The numbers in the $\mathrm{X}$-axis correspond to a specific sample: I- Annobón, 2- Bata, 3- Malabo, 4- Ngonamanga, 5- Sácriba and 6- Libreville. The $Y$-axis represents the probability of assignment of an individual to each cluster. recent colonization of this island, periodical strong fluctuations in effective population size, or a synergistic combination of these factors. Historical data indicates that whilst the first humans arrived to Bioko island ca. 3,000 years ago, Annobón was colonized only in the $15^{\text {th }}$ century by slaves from Angola and São Tomé and Príncipe [52]. Periodic demographic oscillations occur in Annobón, associated with seasonal migrations of workers to Bioko island. In addition, most of the human population from the main village (Pale) moves to smaller inland villages during the hurricane season. These demographic fluctuations in the human population might lead to periodical changes in the effective size of the local mosquito populations.

Significant genetic differentiation was observed between $M$ and S-form samples that are less than $10 \mathrm{~km}$ apart within Bioko island. The estimate of $F_{S T}$ was 2 to 4 -fold greater than those among $\mathrm{M}$-form samples from Bioko and the continent (210-236 km apart) and nearly 2-fold greater than the one obtained between the S-form samples of Bioko and Libreville (378 km apart). Similarly, higher $F_{S T}$ values were obtained in all comparisons between the S-form from Libreville and M-form samples from mainland or Bioko island, when compared to the estimate between island and continental S-form. It is unlikely that $F_{S T}$ estimates may have been influenced by the different time of collections between the sample of Libreville (2000) and those from Equatorial Guinea (2003-2004). Microsatellite allele frequencies in A. gambiae s.l. tend to vary little over generations, reflecting large effective population sizes [53,54]. The higher differentiation between $M$ and $\mathrm{S}$ forms was also evident from the assignment tests performed in the present study, in which most mis-assignments were shared between samples of the same molecular form regardless of its geographic origin. Bayesian cluster analysis further supported this partitioning, by grouping together $\mathrm{M}$ and $\mathrm{S}$ form samples in two separate clusters, again independently of sample location. In a previous study, a significant $F_{S T}$ estimate $(0.070)$ had also been obtained by microsatellite analysis, between sympatric $M$ and $S$ forms from Malabo [55]. 
Altogether, these results agree with the notion of a biological discontinuity within A. gambiae s.s., and that $\mathrm{M}$ and $\mathrm{S}$ forms are likely to be the result of an on-going incipient speciation process [6]. Evidence of limited gene flow between molecular forms has been described in other West African countries, with different genetic markers $[4,8,13,56,57]$. However, several studies, some of which based on microsatellites, suggest that the highest genetic differentiation between $M$ and $S$ forms appears to be restricted mainly to certain genomic regions, particularly in the low-recombination centromeric regions of chromosome $\mathrm{X}$ and chromosome $2 \mathrm{~L}[32,58-61]$. This led the authors to hypothesise that these regions contain genes responsible for reproductive isolation. In this study, high differentiation between $\mathrm{M}$ and S-forms was detected by the analysis of microsatellites mapped in chromosome 3, i.e. outside regions where putative isolation genes are thought to occur, reinforcing the idea of high levels of genetic isolation between molecular forms in this geographic region. Similarly, Wondji et al [16] also observed high differentiation between sympatric $\mathrm{M}$ and S-forms in Cameroon, with the analysis of microsatellites located outside the centromeric regions of chromosomes $2 \mathrm{~L}$ and $\mathrm{X}$. Whilst their results may appear conflicting with those from Turner et al [59], given that both studies were based on samples from Cameroon, this may not be case as different genetic markers (i.e. microsatellites and microarray probes) were used. Microsatellites detect allele frequency differences in highly polymorphic regions of the genome, while hybridization approaches using microarrays will detect differentiation in regions where polymorphism is relatively low within each form relative to differences between forms, such as the case of centromeric regions. On the other hand, in a recent microsatellite-based study carried out in Ghana, levels of population differentiation in A. gambiae s.s.were more attributable to ecological zones rather than to the M-S molecular form partitioning [49]. These apparent differences may suggest that, although it is clear that incipient speciation is on-going within A. gambiae s.s., the degree of isolation between its reproductive units is likely to vary throughout the species eco-geographic distribution range.

Within the M-form, the low levels of differentiation between the sample of Bioko and those from continental Equatorial Guinea suggest that gene flow between this island and the mainland is likely to occur. Reimer et al [55] detected slightly higher levels of population differentiation between Bioko island (Malabo) and sites from the nearest continental country, Cameroon $\left(F_{S T}\right.$ : 0.0380.057). Being the capital of the country, connections with continental Equatorial Guinea (Bata), by air or sea at a daily frequency, may promote gene flow through humanmediated transportation of mosquitoes. Several studies provided evidence of human activities promoting gene flow in mosquito populations between islands or between islands and mainland [62]. Conversely, the highest levels of population differentiation were found in all comparisons that involved the M-form sample of Annobón island. This supports a higher degree of isolation of this island and agrees with previous studies demonstrating the ocean and other extensive water-bodies as a physical barrier to gene flow in anopheline species $[18,19,24,63]$. Similarly, microsatellite-based studies conducted in the neighbouring STP islands also showed high levels of differentiation with the continent $\left(F_{S T}: 0.118-\right.$ 0.250 ) [18] and subsequent sequencing analysis of rDNA and mitochondrial DNA regions suggests only two main colonization events of $A$. gambiae s.s. into these islands [Marshal et al, unpublished].

\section{Conclusion}

In the present study, strong levels of population substructure were detected in A. gambiae s.s. from Equatorial Guinea. Patterns of genetic differentiation are most likely governed by the presence of both physical/geographic (the ocean) and biological (the M-S form discontinuity) barriers to gene flow. These findings have important practical implications for the management of vector control strategies. The biological partitioning between $\mathrm{M}$ and Sforms may influence the evolution of genes of interest such as insecticide resistance genes. An unusual frequency of knockdown resistance $(k d r)$ mutations has been detected in the M-form population of Bioko, contrasting with the absence of these alleles in the S-form of this island [55]. This implies that a detailed characterization of the distribution of $\mathrm{M}$ and $\mathrm{S}$ forms at a local level and continuous monitoring of $k d r$ mutations within each form would be desirable for a rational management of insecticides for malaria control. The closest proximity and lowest differentiation with mainland coupled with the genetic isolation found between sympatric $\mathrm{M}$ and $\mathrm{S}$ form populations in Bioko, could make this island inappropriate for initial experimental releases of genetically modified mosquitoes, as only part of the vector population might be affected. On the other hand, in Annobón the presence of a single molecular form coupled with its higher geographic and genetic isolation, might render this island comparatively more suitable for transgenic-based malaria control.

\section{Authors' contributions}

MM was involved in the design of the survey, microsatellite genotyping, data analysis and manuscript preparation. PS participated in data analysis and drafting the manuscript. JLV carried out microsatellite and data analysis. JC participated in field surveys and helped drafting the manuscript. PB and AL participated in molecular analyses and in the elaboration of the manuscript. FS and AC were involved in sample collections, molecular analyses and 
revised the manuscript. VER participated in the design of the study and revised the manuscript. JP conceived and co-supervised the study, assisted data analysis and coordinated the draft of the manuscript. $\mathrm{AB}$ participated in the conception and design of the study, revised the manuscript and provided overall supervision to the work. All authors read and approved the final manuscript.

\section{Acknowledgements}

We would like to thank the National Malaria Control Program, Republic of Equatorial Guinea's Ministry of Health and Social Welfare, for its technical support. We are grateful to L. Bobuakasi, S. Nzambo, M. Ondó, JN Buatiché and J.C. Toto for helping in mosquito collections. This study received financial support from the Spanish International Cooperation Agency (AECl), the Institute of Health Carlos III within the Network of Tropical Diseases Research Centers (RICET; Proj. Ro6/002I/0000) and from the UNICEF/ UNDP/World Bank/WHO Special Programme for Research and Training in Tropical Diseases (TDR, A50239)

\section{References}

I. WHO/UNICEF/RBM: World Malaria Report 2005. WHO/HTM/MAL/ 2005. I I 02 World Health Organization, Geneva; 2005.

2. Brogdon WG, McAllister JC: Insecticide resistance and vector control. Emerg Infect Dis 1998, 4:605-613.

3. Brey PT: Anopheles gambiae genome: perspectives for malaria control. Mol Cells 2003, 15:133-138.

4. Lehmann T, Licht M, Elissa N, Maega BT, Chimumbwa JM, Watsenga FT, Wondji CS, Simard F, Hawley WA: Population Structure of Anopheles gambiae in Africa. J Hered 2003, 94:133-147.

5. Coluzzi M, Petrarca V, Di Deco M: Chromosomal inversion intergradation in incipient speciation in Anopheles gambiae. Boll Zool 1985, 52:45-63.

6. Della Torre A, Costantini C, Besansky NJ, Caccone A, Petrarca V, Powell JR, Coluzzi M: Speciation within Anopheles gambiae - the glass is half full. Science 2002, 298: II $15-117$.

7. Touré YT, Petrarca V, Traoré SF, Coulibaly A, Maiga HM, Sankare O, Sow M, Di Deco MA, Coluzzi M: The distribution and inversion polymorphism of chromosomally recognized taxa of the Anopheles gambiae complex in Mali, West Africa. Parassitologia 1998, 40:477-5II.

8. Della Torre A, Akogbeto M, Sou-Yovo J, Favia G, Petrarca V, Coluzzi M: Molecular evidence of incipient speciation within Anopheles gambiae s.s. in West Africa. Insect Mol Biol 200I, 10:9-18.

9. Gentile G, Slotman M, Ketmaier V, Powell JR, Caccone A: Attempts to molecularly distinguish cryptic taxa in Anopheles gambiae s.s. Insect Mol Biol 200I, I 0:25-32.

10. Diabate A, Dabire RK, Millogo N, Lehmann T: Evaluating the effect of postmating isolation between molecular forms of Anopheles gambiae (Diptera: Culicidae). J Med Entomol 2007, 44:60-64.

11. Tripet F, Toure YT, Taylor CE, Norris DE, Dolo G, Lanzaro GC: DNA analysis of transferred sperm reveals significant levels of gene flow between molecular forms of Anopheles gambiae. Mol Ecol 200I, 10:1725-1732.

12. Fanello C, Petrarca V, della TA, Santolamazza F, Dolo G, Coulibaly M, Alloueche A, Curtis CF, Toure YT, Coluzzi M: The pyrethroid knock-down resistance gene in the Anopheles gambiae complex in Mali and further indication of incipient speciation within An. gambiae s.s. Insect Mol Biol 2003, I 2:24I-245.

13. Gentile G, Santolamazza F, Fanello C, Petrarca V, Caccone A, della Torre A: Variation in an intron sequence of the voltage-gated sodium channel gene correlates with genetic differentiation between Anopheles gambiae s.s. molecular forms. Insect Mol Biol 2004, I 3:37|-377.

14. Donnelly MJ, Simard F, Lehmann T: Evolutionary studies of malaria vectors. Trends Parasitol 2002, 18:75-80.

15. Krzywinski J, Besansky NJ: Molecular systematics of Anopheles : from subgenera to subpopulations. Annu Rev Entomol 2003, 48:111-139.

16. Wondji C, Simard F, Fontenille D: Evidence for genetic differentiation between the molecular forms $M$ and $S$ within the For- est chromosomal form of Anopheles gambiae in an area of sympatry. Insect Mol Biol 2002, I I: I I-19.

17. Lehmann T, Hawley WA, Kamau L, Fontenille D, Simard F, Collins FH: Genetic differentiation of Anopheles gambiae populations from East and west Africa: comparison of microsatellite and allozyme loci. Heredity 1996, 77(Pt 2): 192-200.

18. Pinto J, Donnelly MJ, Sousa CA, Gil V, Ferreira C, Elissa N, Do Rosario VE, Charlwood JD: Genetic structure of Anopheles gambiae (Diptera: Culicidae) in Sao Tome and Principe (West Africa): implications for malaria control. Mol Ecol 2002, I I:2183-2187.

19. Simard F, Fontenille D, Lehmann T, Girod R, Brutus L, Gopaul R, Dournon $C$, Collins FH: High amounts of genetic differentiation between populations of the malaria vector Anopheles arabiensis from West Africa and eastern outer islands. Am J Trop Med Hyg 1999, 60:1000-1009.

20. Slotman MA, Mendez MM, Torre AD, Dolo G, Toure YT, Caccone A: Genetic differentiation between the BAMAKO and SAVANNA chromosomal forms of Anopheles gambiae as indicated by amplified fragment length polymorphism analysis. Am J Trop Med Hyg 2006, 74:64I-648.

21. Slotman MA, Tripet F, Cornel AJ, Meneses CR, Lee Y, Reimer LJ, Thiemann TC, Fondjo E, Fofana A, Traore SF, Lanzaro GC: Evidence for subdivision within the M molecular form of Anopheles gambiae. Mol Ecol 2007, 16:639-649.

22. Berzosa PJ, Cano J, Roche J, Rubio JM, Garcia L, Moyano E, Guerra A, Mateos JC, Petrarca V, Rosario VE, Benito A: Malaria vectors in Bioko Island (Equatorial Guinea): PCR determination of the members of Anopheles gambiae Giles complex (Diptera: Culicidae) and pyrethroid knockdown resistance (kdr) in An. gambiae sensu stricto. J Vector Ecol 2002, 27: $102-106$.

23. Pardo G, Descalzo MA, Molina L, Custodio E, Lwanga M, Mangue C, Obono J, Nchama A, Roche J, Benito A, Cano J: Impact of different strategies to control Plasmodium infection and anaemia on the island of Bioko (Equatorial Guinea). Malar J 2006, 5: 10.

24. Kayondo J, Mukwaya L, Stump A, Michel A, Coulibaly M, Besansky N, Collins FH: Genetic structure of Anopheles gambiae populations on islands in northwestern Lake Victoria, Uganda. Malar J 2005, 4:59.

25. Gillies MT, Coetzee MT: A Supplement to the Anophelinae of Africa south of the Sahara (Ethiopian zoogeographical region). S Afr Ins Med Res 1987, 2:55.

26. Collins FH, Finnerty V, Petrarca V: Ribosomal DNA-probes differentiate five cryptic species in the Anopheles gambiae complex. Parassitologia 1988, 30:231-240.

27. Scott JA, Brogdon WG, Collins FH: Identification of single specimens of the Anopheles gambiae complex by the polymerase chain reaction. Am J Trop Med Hyg 1993, 49:520-529.

28. Favia G, Lanfracotti A, Spanos L, Siden K, Louis C: Molecular characterization of ribosomal DNA polymorphisms discriminating among chromosomal forms of Anopheles gambiae s.s. Insect Mol Biol 200I, 10:19-23.

29. Pinto J, Lynd A, Elissa N, Donnelly MJ, Costa C, Gentile G, Caccone A, do Rosario VE: Co-occurrence of East and West African kdr mutations suggests high levels of resistance to pyrethroid insecticides in Anopheles gambiae from Libreville, Gabon. Med Vet Entomol 2006, 20:27-32.

30. Zheng L, Benedict MQ, Cornel AJ, Collins FH, Kafatos FC: An integrated genetic map of the African human malaria vector mosquito, Anopheles gambiae. Genetics 1996, I 43:94I-952.

31. Lanzaro GC, Touré YT, Carnahan J, Zheng L, Dolo G, Traoré , Petrarca V, Vernick KD, Taylor CE: Complexities in the genetic structure of Anopheles gambiae populations in west Africa as revealed by microsatellite DNA analysis. Proc Natl Acad Sci USA 1998, 95: I4260-14265.

32. Stump AD, Shoener JA, Costantini C, Sagnon N, Besansky NJ: Sexlinked differentiation between incipient species of Anopheles gambiae. Genetics 2005, 169:1509-1519.

33. Donnelly MJ, Cuamba N, Charlwood JD, Collins FH, Townson H: Population structure in the malaria vector, Anopheles arabiensis Patton, in East Africa. Heredity 1999, 83(Pt 4):408-4I7.

34. Nei M: Molecular Evolutionary Genetics New York: Columbia University Press; 1987.

35. El Mousadik A, Petit R: High level of genetic differentiation for allelic richness among populations of the argan tree Argania 
spinosa L.) Skeels endemic to Morocco. Theoret Appl Genet 1996, 92:832-839.

36. Goudet J: FSTAT Version I.2: A computer program to calculate F-statistics. J Hered 1995, 86:485.

37. Raymond M, Rousset F: GENEPOP (Version I.2): Population genetics software for exact tests and ecumenism. J Hered 1995, 86:248-249.

38. Cornuet JM, Luikart G: Description and power analysis of two tests for detecting recent population bottlenecks from allele frequency data. Genetics 1996, I 44:200I-20I4.

39. Weir BS, Cockerham CC: Estimating F-statistics for the analysis of population structure. Evol I984, 38: | 358-I370.

40. Schneider S, Roessli D, Excoffier L: ARLEQUIN, Version 2 000: A software for population genetics data analysis. 2000 .

41. Rousset F: Genetic differentiation and estimation of gene flow from F-statistics under isolation by distance. Genetics 1997, 145: 12 19-1228.

42. Piry S, Alapetite A, Cornuet JM, Paetkau D, Baudouin L, Estoup A: GENECLASS2: a software for genetic assignment and firstgeneration migrant detection. J Hered 2004, 95:536-539.

43. Rannala B, Mountain JL: Detecting immigration by using multilocus genotypes. Proc Natl Acad Sci USA 1997, 94:91 97-9201.

44. Paetkau D, Slade R, Burden M, Estoup A: Genetic assignment methods for the direct, real-time estimation of migration rate: a simulation-based exploration of accuracy and power. Mol Ecol 2004, I 3:55-65.

45. Pritchard JK, Stephens M, Donnelly P: Inference of population structure using multilocus genotype data. Genetics 2000, I 55:945-959.

46. Evanno G, Regnaut S, Goudet J: Detecting the number of clusters of individuals using the software STRUCTURE: a simulation study. Mol Ecol 2005, 14:26 I I-2620.

47. Holm S: A simple sequentially rejective multiple test procedure. Scand J Statistics 1979, 6:65-70.

48. Onyabe DY, Conn JE: Genetic differentiation of the malaria vector Anopheles gambiae across Nigeria suggests that selection limits gene flow. Heredity 200I, 87:647-658.

49. Yawson AE, Weetman D, Wilson MD, Donnelly MJ: Ecological zones rather than molecular forms predict genetic differentiation in the malaria vector Anopheles gambiae s.s. in Ghana. Genetics 2007, 175:75I-76I.

50. Gillespie RG, Roderick GK: Arthropods on islands: colonisation, speciation and conservation. Annu Rev Entomol 2002, 47:595-632.

5I. Donnelly MJ, Licht MC, Lehmann T: Evidence for recent population expansion in the evolutionary history of the malaria vectors Anopheles arabiensis and Anopheles gambiae. Mol Biol Evol 200I, I 8: I353-1364.

52. Roche J, de Diego JA, Penin P, Santos M, del RJ: An epidemiological study of malaria in Bioko and Annobon islands (Equatorial Guinea). Ann Trop Med Parasitol 1991, 85:477-487.

53. Lehmann T, Hawley WA, Grebert H, Collins FH: The effective population size of Anopheles gambiae in Kenya: implications for population structure. Mol Biol Evol 1998, 15:264-276.

54. Simard F, Lehmann T, Lemasson JJ, Diatta M, Fontenille D: Persistence of Anopheles arabiensis during the severe dry season conditions in Senegal: an indirect approach using microsatellite loci. Insect Mol Biol 2000, 9:467-479.

55. Reimer LJ, Tripet F, Slotman M, Spielman A, Fonjo E, Lanzaro GC: An unusual distribution of the kdr gene among populations of Anopheles gambiae on the island of Bioko, Equatorial Guinea. Insect Mol Biol 2005, 14:683-688.

56. Gentile G, della TA, Maegga B, Powell JR, Caccone A: Genetic differentiation in the African malaria vector, Anopheles gambiae s.s., and the problem of taxonomic status. Genetics 2002, 16I:156I-1578.

57. Boulesteix M, Simard F, Antonio-Nkondjio C, wono-Ambene HP, Fontenille $D$, Biemont $C$ : Insertion polymorphism of transposable elements and population structure of Anopheles gambiae $\mathbf{M}$ and $\mathbf{S}$ molecular forms in Cameroon. Mol Ecol 2007, 16:44I-452.

58. Wang R, Zheng L, Touré YT, Danadekar T, Kafatos FC: When genetic distance matters: measuring genetic differentiation at microsatellite loci in whole genome scans of recent and incipient mosquito species. Proc Natl Acad Sci USA 200I, 98:10769-10774.
59. Turner TL, Hahn MW, Nuzhdin SV: Genomic islands of speciation in Anopheles gambiae. PLoS Biol 2005, 3:e285.

60. Stump AD, Fitzpatrick MC, Lobo NF, Traore S, Sagnon N, Costantini C, Collins FH, Besansky NJ: Centromere-proximal differentiation and speciation in Anopheles gambiae. Proc Natl Acad Sci USA 2005, 102:15930-15935.

6I. Slotman MA, Reimer LJ, Thiemann T, Dolo G, Fondjo E, Lanzaro GC: Reduced recombination rate and genetic differentiation between the $\mathbf{M}$ and $\mathbf{S}$ forms of Anopheles gambiae s.s. Genetics 2006, 174:208I-2093.

62. Lounibos LP: Invasions by insect vectors of human disease. Annu Rev Entomol 2002, 47:233-266.

63. Ayala D, Goff GL, Robert V, de JP, Takken W: Population structure of the malaria vector Anopheles funestus (Diptera: Culicidae) in Madagascar and Comoros. Acta Trop 2006, 97:292-300.
Publish with Bio Med Central and every scientist can read your work free of charge

"BioMed Central will be the most significant development for disseminating the results of biomedical research in our lifetime. "

Sir Paul Nurse, Cancer Research UK

Your research papers will be:

- available free of charge to the entire biomedical community

- peer reviewed and published immediately upon acceptance

- cited in PubMed and archived on PubMed Central

- yours - you keep the copyright

Submit your manuscript here:

http://www.biomedcentral.com/info/publishing_adv.asp
BioMedcentral 